\title{
EXPRESSION OF NEDD9 IN TRANSBRONCHIAL BIOPSIES OF LUNG ADENOCARCINOMA
}

\author{
Jelena Ostojić ${ }^{1}$, Luka Brčíc 2 , Pero Hrabač ${ }^{3}$ and Sven Seiwerth ${ }^{4}$ \\ ${ }^{1}$ Special Hospital for Pulmonary Diseases, Zagreb, Croatia; \\ ${ }^{2}$ Medical University of Graz, Institute of Pathology, Graz, Austria; \\ ${ }^{3}$ School of Medicine, University of Zagreb, Croatian Institute for Brain Research, Zagreb, Croatia; \\ ${ }^{4}$ School of Medicine, University of Zagreb, Institute of Pathology and Zagreb University Hospital Centre, \\ Clinical Department of Pathology and Cytology, Zagreb, Croatia
}

\begin{abstract}
SUMMARY - Lung cancer as the major cause of cancer mortality worldwide includes several histologic subtypes evolving from numerous genetic and epigenetic changes emerging in alveolar, bronchiolar and bronchial epithelium. The majority of cases are diagnosed in advanced stage (i.e. stages IIIB and IV), often with scanty amount of tissue in transbronchial biopsies or cytology specimens. The aim of the present study was to investigate the expression of the scaffolding protein neural precursor cell expressed, developmentally downregulated 9 (NEDD9) in small biopsies of lung adenocarcinoma. The expression of NEDD9 was analyzed immunohistochemically in 71 formalin-fixed and paraffin-embedded transbronchial biopsy specimens of primary lung adenocarcinoma. Nuclear and cytoplasmic NEDD9 expression was detected indicating activation of the epithelial-mesenchymal transition process. Direct relationship between the expression of NEDD9 and survival was not demonstrated.
\end{abstract} Croatia

Key words: Lung Neoplasms; Adenocarcinoma; Biopsy, Needle; Adaptor Proteins, Signal Transducing;

\section{Introduction}

The declining incidence rates of lung cancer in women in the mid-2000s followed the lung cancer decreasing incidence rate in male population in the 1980s as a direct result of the anti-smoking campaigns in previous decades. However, lung cancer is still the leading cause of cancer mortality worldwide ${ }^{1}$. In 2016, lung cancer preceded $14 \%$ and $13 \%$ of the most common newly diagnosed malignances in men and women, respectively, and was the second most common malignancy following prostate cancer in men and breast cancer in women ${ }^{2}$. Since cancer cells have to un-

Correspondence to: Jelena Ostojic, MD, Special Hospital for Pulmonary Diseases, Rockefellerova 3, HR-10000 Zagreb, Croatia E-mail: jelena.ostojic.zg@gmail.com

Received January 18, 2018, accepted March 6, 2018 dergo multiple genetic and epigenetic changes promoting multiplied proliferation potential in parallel with some degree of resistance to programmed cell death during cancer growth, identification of these changes has become an ultimate clinical goal in the past decade. Due to the continuous increase in the incidence of lung adenocarcinoma in the past decades, now it is the most common histologic type of lung cancer $^{3}$.

Neural precursor cell expressed, developmentally downregulated 9 (NEDD9) triggers mitotic checkpoint, regulates cellular attachment and migration, and ciliary resorption, but also apoptosis and anoikis, i.e. programmed cell death due to the loss of attachments. NEDD9 is involved in the control of cellular differentiation, migration and chemotaxis, acting as a scaffolding protein in the complex process of epithelial-mes- 

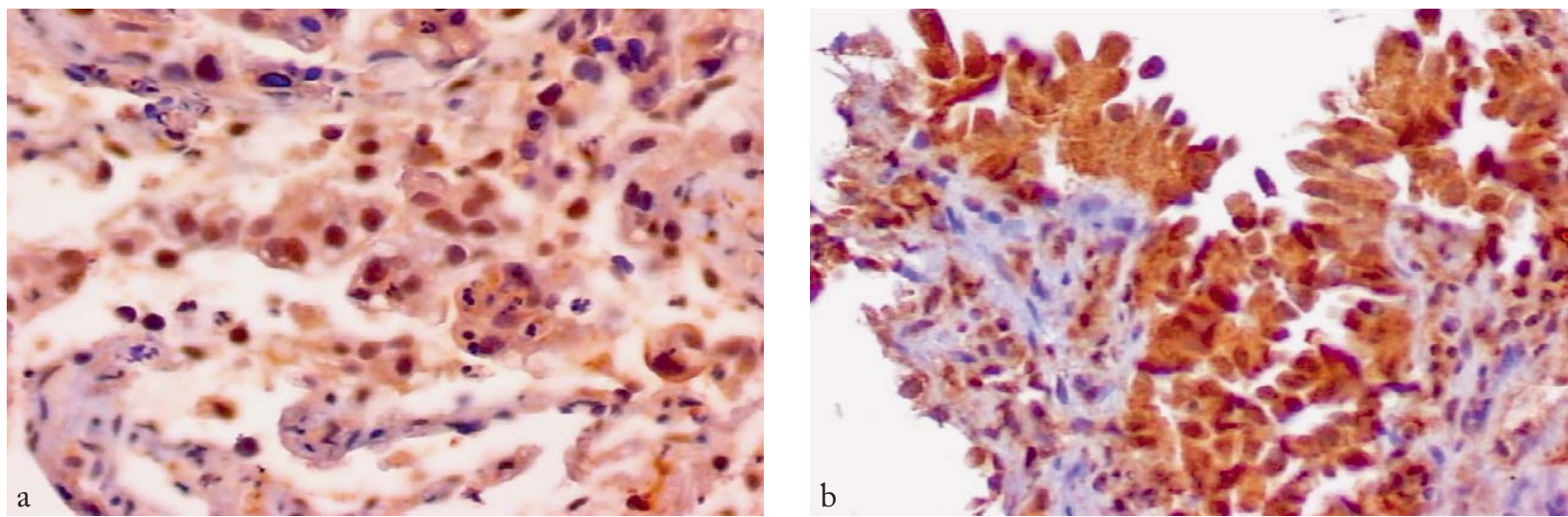

Fig. 1. (a) Strong nuclear expression of NEDD9 in lung adenocarcinoma (x400); (b) strong cytoplasmic expression of NEDD9 in lung adenocarcinoma ( $x 400)$.

enchymal transition (EMT) ${ }^{4}$. NEDD9 has been identified as an integral part of the complex process of metastatic potential acquisition in mammary adenocarcinoma, glioblastoma and metastatic melanoma ${ }^{5-7}$. Moreover, some recent data suggested correlation between NEDD9 expression in resected specimens of lung adenocarcinoma and survival ${ }^{8}$.

However, lung carcinomas are often diagnosed in scanty amounts of tissue obtained by transbronchial biopsies or in cytology samples in up to $70 \%$ of all cases, even in the high-resource centers. Therefore, we aimed to investigate the expression of NEDD9 and its correlation with survival in small biopsy samples of lung adenocarcinoma.

\section{Materials and methods}

\section{Materials}

Out of 90 formalin-fixed paraffin-embedded routine diagnostic transbronchial biopsies from the archives of the Institute of Pathology, School of Medicine, University of Zagreb, 71 were eligible for the study conducted between January 2002 and December 2004. Identity protection was in strict accordance with the Declaration of Helsinki, $7^{\text {th }}$ revision. Patient survival was defined as the time elapsed from the date of tissue collection to the end of the follow-up period or the date of death according to the National Cancer Registry. The samples were stained with hematoxylin and eosin and the diagnosis was confirmed by immunochemistry using TTF-1, CK7 and napsin A panel of antibodies for adenocarcinoma confirmation and p63 and CK5/6 antibodies to exclude squamous cell carcinoma.

\section{Methods}

Immunohistochemistry was performed on $4 \mu \mathrm{m}$ thick sections by standard protocols with primary antibodies including TTF-1 (Novocastra, Great Britain), CK7 (Dako, Denmark), napsin A (Novocastra, Great Britain), CK5/6 (Dako, Denmark) and p63 (Novocastra, Great Britain).

The NEDD9 monoclonal antibody (Abcam, San Francisco, CA, USA) was used in 1:400 dilution with EnVision kit for visualization. Normal bronchial epithelium present in tumor surroundings was used as negative control. The 'hot spot' was determined by inspection on whole specimen at $\mathrm{x} 40$ magnification by two investigators blinded for the clinicopathologic data. The immunohistochemical reaction was examined at $\times 400$ magnification.

The percentage of NEDD9 positive tumor cells was assessed semiquantitatively, as follows: $0-25 \%$ of positive cells scored 0 or negative; $26 \%-50 \%$ as 1 (weakly positive); $51 \%-75 \%$ as 2 (mildly positive); and more than $75 \%$ of positive tumor cells as 3 (strongly positive). Positivity was evaluated separately for nuclei and cytoplasm. The intensity of staining was also scored in the range of 0-3 (negative, weakly stained, mildly or strongly stained) (Fig. 1).

\section{Statistical analysis}

All data analyses were performed using IBM SPSS Statistics, version 24.0. Quantitative data distribution 
was analyzed by the Kolmogorov-Smirnov test, correlations between categorical and nominal data were analyzed using the $\chi^{2}$-test, and correlations between immunoreactivity and survival by Spearman's coefficient of correlation. Survival curves were generated using the Kaplan-Meier method and the log-rank test was performed for survival data analysis. The level of statistical significance was set at $\mathrm{p}<0.05$.

\section{Results}

Seventy-one out of 90 selected transbronchial biopsy samples were eligible for analysis; 8 samples contained insufficient tumor tissue for further analysis, 7 were pulmonary metastases, immunohistochemically confirmed, and 4 were diagnosed as squamous cell carcinomas.

Fifty-five out of 71 lung adenocarcinoma cases were male (77.5\%). Mean age of all patients was 74.3 years. The patients diagnosed with pulmonary adenocarcinoma were part of a larger cohort study and the diagnosis was confirmed by immunohistochemical staining for TTF-1, CK7, p63, CK5/6 and napsin A. Table 1 shows results of testing for different antibodies, and Table 2 shows different combinations of antibodies found positive in study subjects.

Assessment methods (percentage scale of staining intensity and semiquantitative scale) correlated significantly $(\mathrm{p}<0.001)$ in both nuclei and cytoplasm, with Spearman correlation coefficient of 0.905 for nuclei and 0.786 for cytoplasm. Because of such high correlation coefficients, suggesting both scales to measure the same attribute, only the latter (semiquantitative) method will be discussed hereafter. Table 3 shows the number and percentage of specimens by the intensity of NEDD9 staining of both nucleus and cytoplasm.

Analysis of staining results for the nuclei and cytoplasm of our samples revealed an inverse pattern in staining intensity between them, i.e. only a small fraction of nuclei stained with intensity of 3 while a similar small fraction of cytoplasm stained with intensity of 0 . To overcome this, further grouping of staining categories was performed, so that groups 0 and 1 were merged, as well as groups 2 and 3. Survival analysis was performed on such transformed groups of NEDD9 staining intensity and results are presented in Table 4 and Figure 2. Although the level of statistical significance was not reached, the results suggested stronger
Table 1. Number of specimens positive

for each of antibodies tested

\begin{tabular}{|l|l|}
\hline Antibody & Number (\%) of positive specimens \\
\hline TTF-1 & $38(55.5)$ \\
CK7 & $63(91.3)$ \\
p63 & $1(1.4)$ \\
CK5/6 & $0(0)$ \\
Napsin A & $31(43.7)$ \\
\hline
\end{tabular}

Table 2. Number of specimens positive for different antibody combinations

\begin{tabular}{|l|l|l|l|l|l|l|l|l|l|l|}
\hline Antibody & \multicolumn{7}{|l|}{ Positive $(+/-)$} \\
\hline TTF-1 & - & + & + & - & - & + & - & + & + \\
CK7 & + & + & + & + & - & - & - & - & + \\
p63 & - & - & - & - & - & - & - & - & + \\
CK5/6 & - & - & - & - & - & - & - & - & - \\
Napsin A & - & + & - & + & - & + & + & - & - \\
\hline Total & 25 & 24 & 10 & 3 & 3 & 2 & 2 & 1 & 1 \\
\hline
\end{tabular}

Table 3. Staining intensity for NEDD9 in nuclei and cytoplasm of adenocarcinoma specimens

\begin{tabular}{|l|l|l|}
\hline \multirow{2}{*}{ Staining intensity } & \multicolumn{2}{|l|}{ Number (\%) of specimens } \\
\cline { 2 - 3 } & Nuclei & Cytoplasm \\
\hline 0 & $30(42.3)$ & $7(9.9)$ \\
1 & $10(14.1)$ & $23(32.4)$ \\
2 & $27(38.0)$ & $23(32.4)$ \\
3 & $4(5.6)$ & $18(25.4)$ \\
\hline
\end{tabular}

NEDD9 staining intensity to correlate with longer survival. This was true for both nuclei and cytoplasm staining intensity, with the effect being significantly more pronounced in cytoplasm.

\section{Discussion}

The last decade was characterized by a growing scientific interest for the members of the Crk-associated substrate (CAS) adaptor protein family, namely p130Cas/BCAR1 and NEDD9/HEF1/Cas-L. Although the catalytic function has not yet been demonstrated for any member of the CAS family, it is clear that these proteins serve as hubs for many vital cellular processes owing to multiple protein interaction motifs on their surfaces. NEDD9 has numerous roles in 
Table 4. Mean survival time in months (with 95\% confidence intervals) based on NEDD9 staining intensity

\begin{tabular}{|l|l|l|}
\hline \multirow{2}{*}{ Staining intensity } & \multicolumn{2}{|l|}{ Survival (months) } \\
\cline { 2 - 3 } & Nuclei & Cytoplasm \\
\hline 0 and 1 & $26.7(14.3-39.1)$ & $21.0(8.6-33.4)$ \\
2 and 3 & $35.5(17.4-53.6)$ & $38.1(22.2-54.1)$ \\
$p$ & 0.687 & 0.199 \\
\hline
\end{tabular}

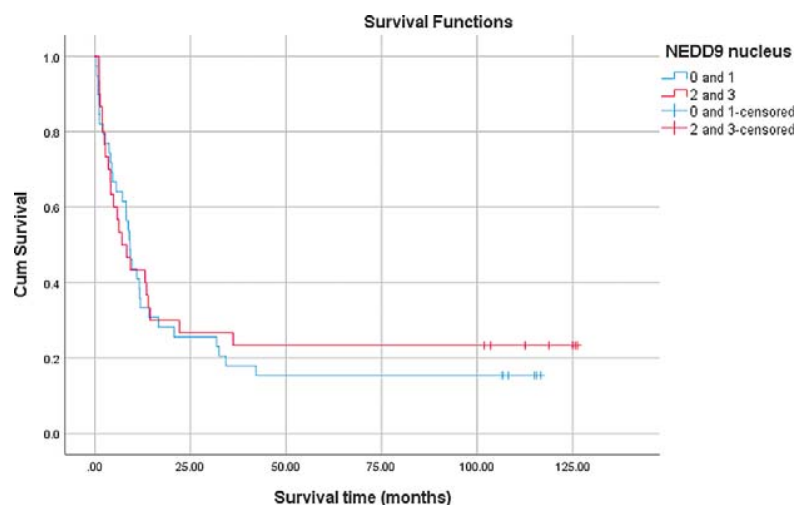

ture with napsin A described as a particularly useful tool in identifying double-negative (TTF-1/CK7) tumors as adenocarcinoma, since it is persistently negative in squamous cell carcinoma ${ }^{10,11}$.

The NEDD9 has been shown to concentrate at focal adhesions in response to binding of various intrinsic and extrinsic partner proteins to the $\mathrm{SH} 3$-domain and highly conserved carboxy-terminal domain that

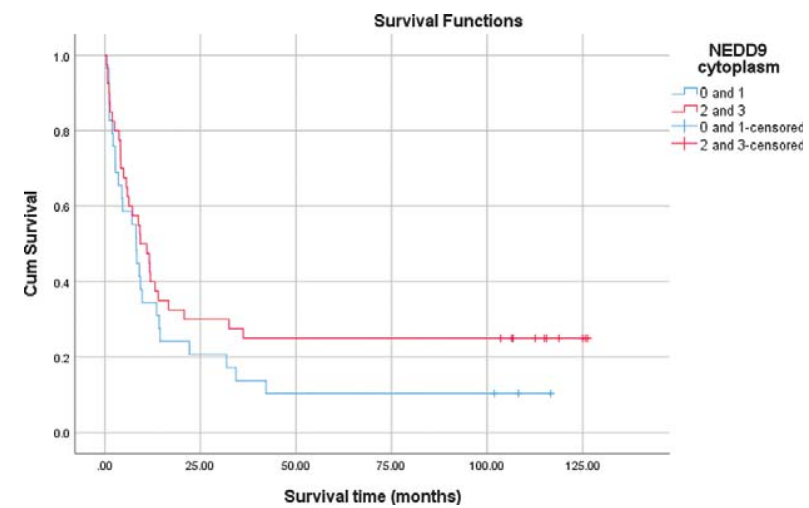

Fig. 2. Survival time in months based on intensity of NEDD9 staining of nuclei (left) and cytoplasm (right) of adenocarcinoma specimens.

modulating and controlling normal cell cycle, cellular attachment, migration and chemotaxis, and therefore has been studied mostly in the context of epithelialmesenchymal transition, i.e. cancer growth, invasion and metastasis formation. To date, overexpression of NEDD9 has been demonstrated in various malignancies. Recently, its positive correlation with lymph node metastasis in non-small cell lung carcinoma (NSCLC) has been described in a series of 105 resected tumors ${ }^{8}$. However, since the vast majority of lung cancers are diagnosed by use of small biopsy and cytology specimens, we aimed to analyze NEDD9 expression and its correlation with survival in small biopsy samples of lung adenocarcinoma diagnosed according to the latest World Health Organization classification of lung tumors 9 . To our knowledge, our study is the first one analyzing NEDD9 expression in transbronchial biopsies of lung adenocarcinoma.

In our series of transbronchial biopsies, the diagnosis of adenocarcinoma was confirmed by TTF-1, CK7 and/or napsin A positive reaction. Of note, napsin A stained positive in $8(11.3 \%)$ cases of TTF-1-negative tumors, two of which were double-negative for TTF$1 / \mathrm{CK} 7$. This finding has been reported in recent litera- allows homo- and heterodimerization of the NEDD9 molecule and subsequent interaction with downstream molecules mediating cellular migration. Also, NEDD9 concentrates at the mitotic spindle and interacts with the centrosome and proteasomal machinery with both nuclear and cytoplasmic pools, where its expression and activities are closely regulated by rapid turnover ${ }^{12}$. In our study, significant levels of expression were found in both nuclear $(41 / 71,57.7 \%)$ and cytoplasmic departments $(64 / 71,90.1 \%)$ of adenocarcinoma cells. This finding is in concordance with the results of an earlier study in which Chang et al. investigated NEDD9 localization and expression in 60 cases of surgically treated lung adenocarcinoma ${ }^{13}$. It has been postulated that NEDD9 serves as a sort of switch driving cell migration in the early stages of neoplastic transformation and contributes to the invasive properties $^{14}$. McLaughlin et al. found that increased expression of NEDD9 correlated with the transformation from breast carcinoma in situ to invasive tumor ${ }^{15}$. On the other hand, NEDD9 expression correlated inversely with recurrence-free survival, but also in patients treated with curative surgery, i.e. earlier stages of the disease ${ }^{16}$. Furthermore, NEDD9 expression was 
correlated with smoking history, TNM stage and lymph node metastasis (but with no apparent correlations with other clinical features), indicating the role of NEDD9 in the disease progression ${ }^{17}$. Recently, Miao et al. demonstrated inverse correlation between NEDD9 expression and overall survival in patients with resectable NSCLC (but interestingly, not with the TNM stage $)^{8}$. In our study, the investigated relationship between NEDD9 expression and survival did not reach statistically significant difference. Quite surprisingly, there was a trend towards correlation of stronger NEDD9 staining intensity to longer survival. This was true for both nuclear and cytoplasmic expression, with the effect being significantly more pronounced in cytoplasm. Considering numerous functions of NEDD9 in complex processes of cellular differentiation and migration, it is expected that the overexpression in lung carcinomas is a marker of a higher malignant potential. On the other hand, it has been demonstrated that expression of NEDD9 over certain level inevitably leads to apoptosis ${ }^{18}$. Furthermore, Minn et al. independently demonstrated down-regulation of NEDD9 as part of metastatic signature in mammary tumors ${ }^{19}$. It is plausible to conclude that the levels of NEDD9 must be precisely and timely regulated, and the overexpression can be tolerated only in tumor cells with extensive prior lesions that enable escaping cellular death. It is also possible that elevated expression of NEDD9 may indicate better responses to therapy ${ }^{16}$. Pallarès et al. have described unexpected discovery of NEDD9 (but not BCAR1) expression as an independent prognostic factor of favorable prognosis in intermediate-risk acute myeloid leukemia, which is in contrast with the previously reported higher aggressiveness in BCR-ABL-dependent acute lymphoblastic leukemia ${ }^{20}$.

We demonstrated both nuclear and cytoplasmic expression of NEDD9 in transbronchial biopsies of lung adenocarcinoma indicating activation of the epithelial-mesenchymal transition process. However, we were unable to demonstrate relationship between the expression of NEDD9 and survival.

Our study had several limitations; data were obtained on a rather small population, with the possibility of selection bias, and it was performed on small biopsies. It would be of interest to extend our study to the resected tumors and correlate these results with other clinical parameters (such as TNM stage, tumor size, and response to therapy) in a larger group. Taking into account the complex functions of NEDD9 and precise regulation of numerous different interconnected signaling networks, more future studies are warranted before targeting NEDD9 as one of the possible routes in precision oncology.

\section{References}

1. Giovino GA. Epidemiology of tobacco use in the United States. Oncogene. 2002;21:7326-40. doi: $10.1038 /$ sj.onc.1205808

2. Siegel RL, Miller KD, Jemal A. Cancer statistics, 2016. CA Cancer J Clin. 2016;66(1):7-30. doi: 10.3322/caac.21332.

3. Howlader N, Noone AM, Krapcho M, Miller D, Bishop K, Kosary CL, et al. (eds). SEER Cancer Statistics Review, 19752014, National Cancer Institute. Bethesda, MD, https://seer.cancer.gov/csr/1975_2014/

4. Singh MK, Cowell L, Seo S, O’Neill G, Golemis E. Molecular basis for HEF1/NEDD9/Cas-L action as a multifunctional coordinator of invasion, apoptosis and cell cycle. Cell Biochem Biophys. 2007;48(1):54-72.

5. Kong C, Wang C, Wang L, Ma M, Niu C, Sun X, et al. NEDD9 is a positive regulator of epithelial-mesenchymal transition and promotes invasion in aggressive breast cancer. PLoS ONE. 2011;6(7):e22666. doi: 10.1371/journal.pone.0022666

6. Natarajan M, Stewart Jr JE, Golemis EA, Pugacheva EN, Alexandropoulos $\mathrm{K}$, Cox $\mathrm{BD}$, et al. HEF1 is a necessary and specific downstream effector of FAK that promotes the migration of glioblastoma cells. Oncogene. 2006;25:1721-32. doi: 10.1038/sj.onc.1209199

7. Kim M, Gans JD, Nogueira C, Wang A, Paik JH, Feng B, et al. Comparative oncogenomics identifies NEDD9 as a melanoma metastasis gene. Cell. 2006;125:1269-81. doi: 10.1016/j.cell.2006.06.008

8. Miao Y, Li AL, Wang L, Fan CF, Zhang XP, Xu HT, et al. Overexpression of NEDD9 is associated with altered expression of $\mathrm{E}$-cadherin, $\beta$-catenin and $\mathrm{N}$-cadherin and predictive of poor prognosis in non-small cell lung cancer. Pathol Oncol Res. 2013;19(2):281-6. doi: 10.1007/s12253-012-9580-2

9. Travis WD, Brambilla E, Nicholson AG, Yatabe Y, Austin JHM, Beasley MB, et al. The 2015 World Health Organization classification of lung tumors. Impact of genetic, clinical and radiologic advances since the 2004 classification. J Thorac Oncol. 2015;10(9):1243-60. doi: 10.1097/JTO.0000000000000630

10. Mukhopadhyay S, Katzenstein AL. Subclassification of nonsmall cell lung carcinomas lacking morphologic differentiation on biopsy specimens: utility of an immunohistochemical panel containing TTF-1, napsin A, p63, and CK5/6. Am J Surg Pathol. 2011;35(1):15-25.

doi: 10.1097/PAS.0b013e3182036d05 
11. Rekhtman N, Ang DC, Sima SC, Travis WD, Moreira AL. Immunohistochemical algorithm for differentiation of lung adenocarcinoma and squamous cell carcinoma based on large series of whole-tissue sections with validation in small specimens. Mod Pathol. 2011;24(10):1348-59.

doi: 10.1038/modpathol.2011.92

12. Tikhmyanova N, Little JL, Golemis EA. CAS proteins in normal and pathological cell growth control. Cell Mol Life Sci. 2010;67(7):1025-48. doi: 10.1007/s00018-009-0213-1

13. Chang JX, Gao F, Zhao GQ, Zhang GJ. Role of NEDD9 in invasion and metastasis of lung adenocarcinoma. Exp Ther Med. 2012;4(5):795-800. doi: 10.3892/etm.2012.693

14. Klemke RL, Leng J, Molander R, Brooks PC, Vuori K, Cheresh DA. CAS/Crk coupling serves as a "molecular switch" for induction of cell migration. J Cell Biol. 1998;140(4):961-72.

15. McLaughlin SL, Ice RJ, Rajulapati A, Kozyulina PY, Livengood RH, Kozyreva VK. NEDD9 depletion leads to MMP14 inactivation by TIMP2 and prevents invasion and metastasis. Mol Cancer Res. 2014;12(1):69-81. doi: 10.1158/1541-7786. MCR-13-0300
16. Kondo S, Iwata S, Yamada T, Inoue Y, Ichihara H, Kichikawa Y. Impact of the integrin signaling adaptor protein NEDD9 on prognosis and metastatic behavior of human lung cancer. Clin Cancer Res. 2012;18(22):6326-38. doi: 10.1158/1078-0432. CCR-11-2162

17. Feng Y, Wang Y, Wang Z, Fang Z, Li F, Gao Y, et al. The CRTC1-NEDD9 signaling axis mediates lung cancer progression caused by LKB1 loss. Cancer Res. 2012;72(24):6502-11. doi: 10.1158/0008-5472.CAN-12-1909

18. Pugacheva EN, Golemis EA. HEF1-aurora A interactions: points of dialog between the cell cycle and cell attachment signaling networks. Cell Cycle. 2006;5(4):384-91. doi: $10.4161 /$ cc.5.4.2439

19. Minn AJ, Gupta GP, Siegel PM, Bos PD, Shu W, Giri DD, et al. Genes that mediate breast cancer metastasis to lung. Nature. 2005;436(7050):518-24. doi: 10.1038/nature03799

20. Pallarès V, Hoyos M, Chillón MC, Barragán E, Conde MIP, Llop M, et al. NEDD9, an independent good prognostic factor in intermediate-risk acute myeloid leukemia patients. Oncotarget. 2017;8(44):76003-14. doi: 10.18632/oncotarget.18537

Sažetak

\section{EKSPRESIJA NEDD9 U TRANSBRONHALNIM BIOPTATIMA ADENOKARCINOMA PLUĆA}

\section{J. Ostojić, L. Bröic, P. Hrabač i S. Seiwerth}

Karcinom pluća objedinjuje zloćudne tumore nastale brojnim genetskim i epigenetskim promjenama epitelnih stanica bronha, bronhiola i alveola, i predstavlja najčešći uzrok smrti među malignim bolestima. U većini slučajeva dijagnoza se postavlja u uznapredovalim stadijima bolesti (IIIB. i IV.) iz uzoraka transbronhalnih biopsija ili citoloških materijala. U ovom istraživanju ispitana je ekspresija regulatorne bjelančevine nazvane neural precursor cell expressed, developmentally downregulated 9 (NEDD9) u 71 uzorku malih biopsija adenokarcinoma pluća. Utvrđena je izražena ekspresija NEDD9 u jezgri i citoplazmi stanica adenokarcinoma, koja ukazuje na aktivaciju epitelno-mezenhimne tranzicije. Pritom nije dokazana nedvojbena povezanost ekspresije NEDD9 s preživljenjem.

Ključne riječi: Plućni tumori; Adenokarcinom; Biopsija, punkcijsko-aspiracijska; Adaptorni proteini, prijenosnici signala; Hrvatska 